\title{
Study of Karna Srava (CSOM) and its management with Nasya, Saptnga Guggulu and Gandhakadi Taila Karna Poorana
}

\author{
Research Article
}

\author{
Dave Parth Prakashbhai ${ }^{1^{*}}$, Vaghela DB $^{2}$, Dhiman $\mathrm{KS}^{3}$, Maniyar Hiten \\ 1. Ph.D.(Ayu) Scholar, 2. Assistant Professor, 3. Professor and HOD \\ Dept. of Shalakya, I.P.G.T. \& R.A., GAU, Jamnagar \\ 4. Assistant Professor, Department of ENT, \\ M.P. Shah medical college, Jamnagar
}

\begin{abstract}
Karna Srava (CSOM) is the one of the most common complaint encountered in clinical practice of ENT. CSOM involves 65-330 million individuals with draining ears, 60\% of whom (39-200 million) suffer from significant hearing impairment. In this study an attempt has been made to treat the "disease" with Nasya (Instillation of oil or other medication in nose), Karna Purana (Instillation of oil or other medication in ear) and oral medicine and identifying the etiological factors for the disease and most encountered causes in various age groups. Saptanga Guggulu orally for Dushta Vranahara Chikitsa and Gandhakadi Taila Karna Poorana for local Karna Poorana procedure were selected in this study. As the Pratishyaya (Rhinitis) is the culprit for the disease, in one group Shadbindu Taila Nasya was given for five days before starting treatment. For this study total 28 patients were registered and randomly divided into two groups, among which all patients completed the treatment. The effect of treatment was observed both in subjective symptoms and objective parameters. Significant results were observed in subjective criteria in both groups where insignificant results were obtained in objective criteria in both groups.
\end{abstract}

Key Words: Karna Srava, CSOM, Gandhakadi Taila, Karna Poorana, Nasya.

Introduction:

Karna Srava (Ear discharge) signifies discharge from ear but with advancement of medical science and improved hygienic status of society, ear discharge from the external ear is not very common and discharge from internal ear or other cause is very rare condition. But ear discharge from middle ear cavity is till date a common ENT problem.

CSOM (Chronic Suppurative Otitis Media) is the term given to the middle ear discharging problem in the modern medical literature. Both Ayurveda and modern science agrees unanimously that nose (Rhinitis) and nasopharynx are the main culprits for Karna Srava/CSOM Prevalence surveys, which vary widely in disease definition, sampling methods, and methodological quality, show that the global burden of illness from CSOM involves 65-330 million individuals with draining ears, $60 \%$ of whom (39-200 million) suffer from significant hearing impairment. CSOM accounts for 28, 000 deaths and a disease burden of over two million DALYs (Disease Altered Life Years). Over $90 \%$ of the burden is borne by countries in the South-east Asia and Western Pacific regions, Africa, and several ethnic minorities in the Pacific Rim. CSOM is uncommon in the Americas, Europe, the Middle East, and Australia. The ultimate fate of the tympanic perforation is still largely undocumented (1). In India prevalence for this disease is 
$7.8 \%$, which is considered as high according to WHO. Prevalence is 46 and 16 per thousand in rural and urban population respectively. It is single most important cause for deafness in rural population (2).

As Pratishyaya is the root cause for the disease, Shiro Virechana was selected in one group. Dushta Vranahara Chikitsa and Karna Poorana were advocated in both the groups. Treatment protocol was designed according to Chikitsa Sutra (Line of treatment) given in Sushruta Samhita and Ashtanga Samgraha.

For this study total 28 patients were registered and randomly divided into two groups by simple random sampling method, among which all patients completed the treatment. The effect of treatment was observed both in subjective symptoms and objective parameters.

For the present study Gandhakadi

Taila (3) Karna Poorana, Saptanga Guggulu (4) and Shadabindu Taila (5) were selected as trial drugs.

\section{Materials and Methods}

Aims and objectives:

The present study was based on following aims and objectives:

- Conceptual study of Karna Srava (CSOM).

- To study the etiological factors for different age groups in Karna Srava (CSOM).

- To evaluate the role of trial drugs in the management of Karna Srava (CSOM).

Inclusion criteria:

Patients attending the OPD and IPD of the department of Shalakya of I.P.G.T. \& R.A., Hospital Jamnagar, fulfilling the criteria of selection fulfilling the diagnostic criteria which are based on signs and symptoms of Karna Srava (CSOM) and examination were selected for present study. The special proforma was prepared on Ayurvedic as well as modern guidelines.

Exclusion criteria:

- Patients aged below ten years and above seventy years were excluded.

- Patients having atticoantral type of CSOM.

- Patients suffering from any chronic debilitating disease, with other ear pathology and cases which required surgical intervention were excluded from study.

Investigation:

Following investigations were carried out before treatment to rule out any systemic disease.

- Haemogram: - Hb., T.C, D.C, ESR,

- Bio chemical investigation: - FBS.

- Urine: - Routine \& Microscopic.

- Audiometric and Otoscopic examinations for objective assessments.

This project has been cleared by Institutional Ethics Committee vide its letter No. PGT/7-A/2012-2013/1964, dated: 21/09/2012. This trial was also registered in Clinical Trial Registry of India (CTRI), ref. no REF/2013/09/005653. GROUPING:

- Group- 1:

I. Gandhakadi Taila Karna Poorana , approx. 1ml. in ear once in the evening,

II. Saptnaga Guggulu, 2 tablets each of $500 \mathrm{mg}$ orally thrice daily.

III. Shadabindi Taila Nasya, 6 drops in each nostril was given for 5 days before starting the treatment.

- Group- 2: Same treatment protocol was adopted as group 1 except Nasya.

\section{Duration Of Treatment:}

45 days. One month follow up at intervals of 15 days. 
An assessment was made on symptoms and signs before and after treatment. The scoring was given to each criterion. The following criteria were made to assess effect of therapy.

(Table 1: Criteria for assessment of therapy)

\begin{tabular}{|l|l|l|}
\hline No. & Criteria & Percentage \\
\hline 1 & $\begin{array}{l}\text { Complete } \\
\text { remission }\end{array}$ & $100 \%$ \\
\hline 2 & $\begin{array}{l}\text { Marked } \\
\text { improvement }\end{array}$ & $99-75 \%$ \\
\hline 3 & Moderate imp. & $74-50 \%$ \\
\hline 4 & $\begin{array}{l}\text { Mild } \\
\text { Improvement }\end{array}$ & $49-25 \%$ \\
\hline 5 & Unchanged & $<25 \%$ \\
\hline
\end{tabular}

\section{Stastical analysis:}

The information gathered on the basis of above observations was subjected to statistical analysis in terms of mean (x), standard deviation (S.D.) and standard error (S.E.). Paired ' $t$ ' test was carried out at $\mathrm{P}<0.05, \quad \mathrm{P}<0.01 \quad$ and $\mathrm{P}<0.001$ levels. The obtained results were interpreted as, Insignificant $\quad P>0.05$, Significant $\mathrm{P}<0.05$ or highly significant $\mathrm{P}<0.01$ or $<0.001$.

\section{Observations and results:}

In this clinical trial of total 28 patients were registered, 14 patients in each, among which all completed the treatment.

Majority of the patients $74.97 \%$ belonged to middle class. Maximum numbers of the patients i.e. $46.11 \%$ were from polluted surrounding of residence followed by $39.57 \%$ were from damp surroundings. Majority of the patient i.e.60.69\% were from urban habitat followed by $14.28 \%$ from sea-cost. Maximum numbers of the patients i.e. $53.55 \%$ were working in surrounding with direct exposure to cold and wind. Among
28 patients only one patient was having both family and surgical history positive.

Maximum numbers of patients i.e. $100 \%$ were having CSOM as a sequel to AOM (Acute Otitis Media), Avashyaya (Dew) was seen in $92.82 \%$ of patients followed by Karna Kanduyana (Ear scratching) in $78.54 \%$ of patients, Pratishyaya and Jalakrida (Water games) were as Nidana (Etiological factor) in $71.4 \%$ of patients, repeated infections through ET (Eustachian tube), nasopharynx were found as Nidana in $57.12 \%$ of patients.

Maximum number of patients i.e. $100 \%$ had Karna Srava, followed by 96.38\% patients were having Badhirya (Deafness). $89.25 \%$ of patients had Karna Kandu (Itching in ear), $78.54 \%$ patients had Karna Pratinaha (Feeling of ear blockage) and $21.42 \%$ patients had Karna Nada (Ringing ear/Tinnitus) as symptom. Karna Shula (Earache/Otalgia) was observed in $14.28 \%$ of patients.

In Karna Srava $96.97 \%$ relief was observed in group A and $86.86 \%$ relief was observed in group B.100\% relief was obtained in Karna Shula in both groups. In Karna Kandu $100 \%$ and $81.82 \%$ relief was observed in grup A and group B respectively. In Karna Pratinaha accordingly $73.33 \%$ and $80 \%$ relief was gained respectively in group A and group B. In Karna Nada $75 \%$ and $14.29 \%$ relief was gained respectively in group $\mathrm{A}$ and group B. Only $2.44 \%$ and $10.25 \%$ relief was observed in tympanic membrane perforation in group A and group B respectively. In deafness $15 \%$ and $5.26 \%$ relief was observed in deafness in group A and group B respectively. Group A has better percentage wise result on all chief complains than Group B except Karna Pratinaha, while group B has better result in Karna Pratinaha than group A. 


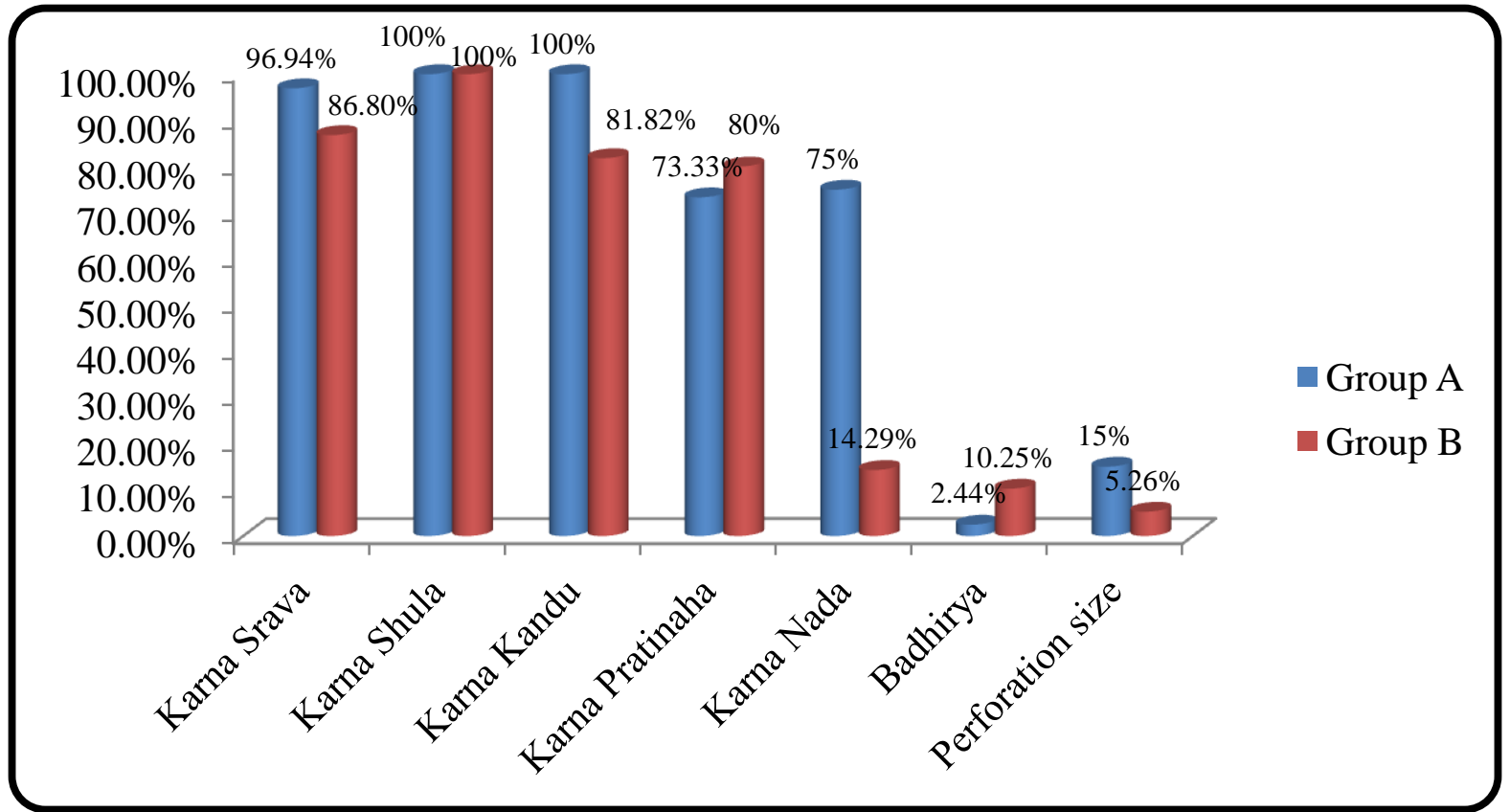

(Comparative effect of therapy on chief complains and objective criteria of Karna Srava (CSOM) (\% relief, $\mathrm{n}=14)$ )

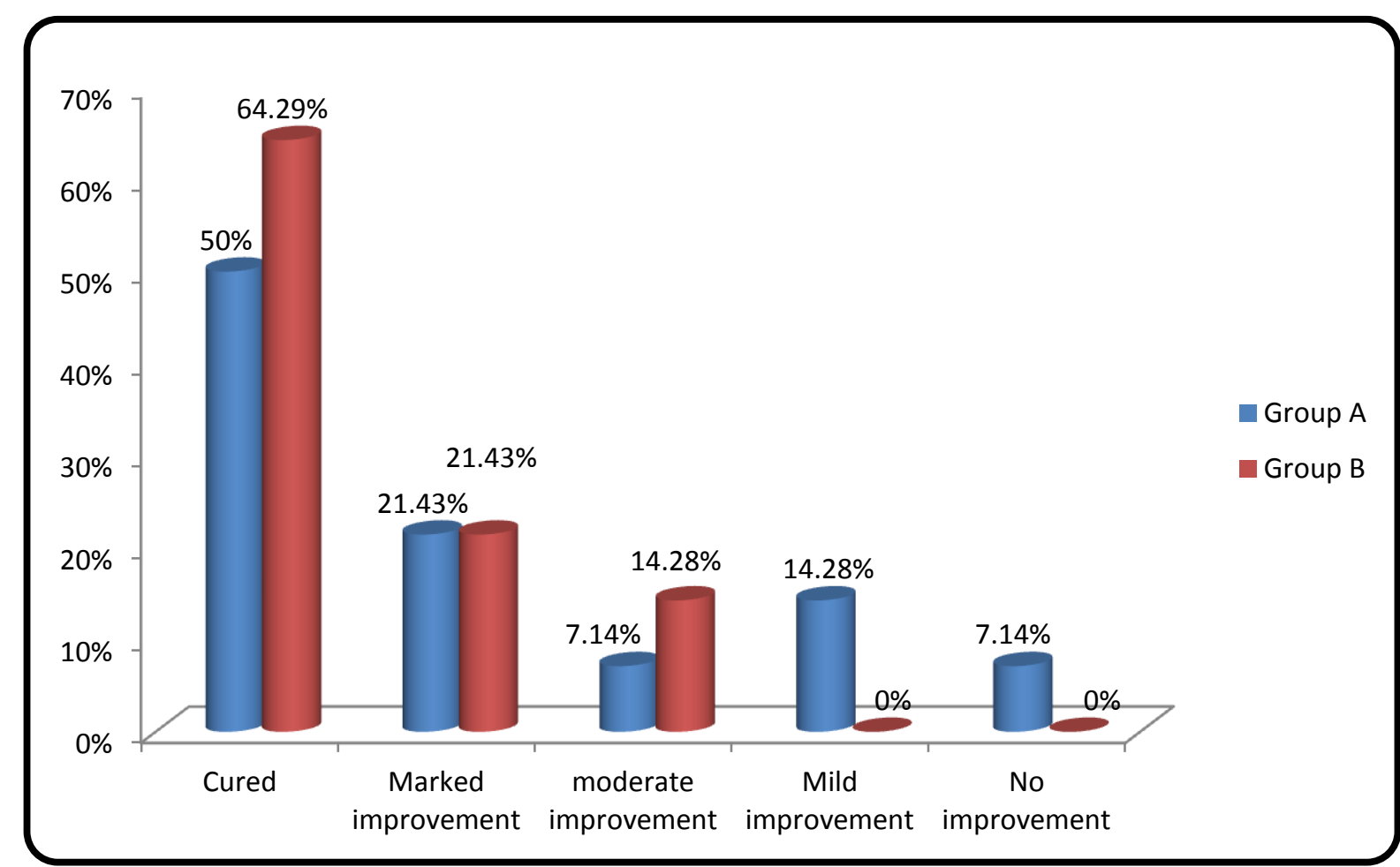

(Assessment of therapy $(n=14))$ 
Complete relief was found in 50\% and $64.29 \%$ of patient in both groups respectively. $21.43 \%$ patients got marked relief in both group. $7.14 \%$ and $14.28 \%$ patients got moderate relief respectively in group A and group B. $14.28 \%$ patients got mild relief and $7.14 \%$ patients got no relief in group A.

\section{Discussion:}

Majority of the patients $74.97 \%$ belonged to middle class. Socio Economic Status is having direct relation with prevalence, lower groups are having high incidence (6). $14.28 \%$ patients were from sea-cost as Jamnagar area is near to sea and Avashyaya is said to be key factor in etiology of Karna Srava by our Aacharya. Family history was found positive in only one patient among 28 which shows that the disease has no genetic pre despondence. Avashyaya was seen in $92.82 \%$ of patients as Jamnagar is near to sea-cost, and patients were having habit of going out in morning for routine work or exercise, this Nidana is almost inescapable for most patients. Karna Kanduyana was observed in $78.54 \%$ of patients, Pratishyaya was detected as Nidana in $71.4 \%$ of patients as it causes tubal occlusion which is prime cause in pathogenesis of CSOM.

Maximum number of patients i.e. $100 \%$ had Karna Srava as it is the principal symptom of disease, followed by $96.38 \%$ patients were having Badhirya (i.e. conductive hearing loss for this study) as the disease affects conductive aperture. $89.25 \%$ of patients had Karna Kandu which can be due to discharge present in EAC, $78.54 \%$ patients had Karna Pratinaha that can be because of discharge and eustechian tube blockage.

In group A statistically highly significant result was obtained in Karna Srava and Karna Kandu as "p" is $<0.001$. On the other hand insignificant results were achieved for Karna Shoola, Karna Pratinaha, Karna Nada as "p" is $>0.05$. This is because in group A oral medicine and Karna Poorana were advocated. Karna Poorana is a local measure which helps in reliving Karna Srava and Karna Kandu. While Karna Pratinaha and Karna Shoola are mainly due to tubal dysfunction local and/or oral medications can not give better results in such pathology.

In group B statistically highly significant result was obtained in Karna Srava, Karna Pratinaha and Karna Kandu as "p" is $<0.001$. Group B showed better results than group A in Karna Pratinaha because in Nasya Karma due to virtues of Sthanika Abhyanga and Swedana mucosal edema of eustechian tube decreases. With help of slight head low posture and little forceful inhalation drug reaches to the sinuses, middle ear (via eustechian tube) olfactory area and cranial cavity. It opens the eustechian tube which is the culprit for the disease Karna Srava (CSOM). On the other hand insignificant results were obtained for Karna Shoola, Karna Nada as " $p$ " is $>0.05$.

Insignificant results were obtained for Karna Shula and Karna Nada as among 28 patients only 2 and 4 patients respectively were having complains of Karna Shula and Karna Nada and though they got relief it was not possible to evaluate results statistically. Results in objective criteria were statistically insignificant for group A and group B both. Among twenty eight patients perforation was healed in only two patients in group B and size was reduced from small to tiny in one patient in group $B$, as these patients were from younger age group and having good Bala and were having a shorter history than other patients. Appearance of pinkish margins was noted in many patients but perforation did not heal as perforation size was not tiny or small. In addition to this, avoidance of Nidana was not possible for them. Patients got subjective relief in deafness, but in PTA there was no change than before. Hearing threshold was improved in many patients but those changes were not 
sufficient to have effect on the criteria for deafness in audiometric examination. In audiometric examinations further advancement of deafness or any sensory neural deafness was not found that shows systemic and local drugs are not having any ototoxic effects.

Probable mode of action:

All drugs in Gandhakadi Taila mentioned in Karna Rogadhikara are Ushna Virya and Katu Vipaki thus it eliminates Kapha. Haridra is having Vrana Shodhana, Vrana Ropana properties this promotes healing of tympanic membrane perforation. With help of Laghu-Ruksha Guna of Hridra and Dhatura Kapha is eliminated and Ruksha is helpful in discharging condition. Laghu Guna is Lekhana and Vrana Ropana, and Varnakara (7). Gandhaka and Manahshila are having Rasayana property. Haridra and Sarshapa also possess anti fungal property by this virtue fungal infection of ear which is seen due to inadequate care by patient after Karna Poorana or as a complication of CSOM is prevented. All drugs used are having strong insecticidal and anti bacterial activities thus help in elimination of local infection. On analytic study this formulation was found to seize high acid value (33.653) for this reason it removes squamous epithelium from margin of perforation that is the reason for permanent perforation, same principle is applied in allopathic medicine in chemical cauterization by $\mathrm{AgNO}_{3}, \mathrm{TCA}$ etc.

Ingredients of Saptanga Guggulu mentioned in Nadivrana Prakarana are having Kaphaghna, Vedanasthapana, Deepana, Pachana. Anulomana, Dhatu Vardhaka hence all these help in chronic condition of like CSOM and elimination of Pratishyaya and Kapha. Guggulu is Shodhana, Ropana thus helps in wound healing and promotes healing of tympanic perforation. Shoola-prashamana, Krimighna properties are useful in condition of Karna Shula and infection.
Rasayana and Nadi Balya properties prevent cochlear damage due to disease. Aamalaki, Pippali and Shunthi are having beneficial effects on immune system so this formulation boosts immune system and repeated infections are prevented. Nearly all drugs are having antiinflammatory, anti microbial and anti bacterial properties which is helpful in systemic eradication of disease and mucosal edema of eustechian tube which is main culprit in the disease.

Most drugs used in Shadabindu Taila mentioned in Shiro Rogadhikara are having Tikshana, Ushna Virya, Katu Vipaki properties this is how they work as Kaphahara, Vata Anulomana, Shirovirechana. Vidanga is said to be Useful in Jirna Pratishyaya and Twaka is Peenasanashna by this way this formulation helps in elimination of Pratishyaya which is a main factor for CSOM. This is how this drug works in complete eradication of disease. Karkatashrungi is Anti-allergic and Aeranda Moola is having immunizing property by these virtues it helps in controlling allergy which is the important cause in pathogenesis of CSOM. Utmost drugs are having anti-bacterial and/or antiinflammatory activities so Shadabindu Taila eradicates local and systemic infections, decreases mucosal edema of Eustachian tube and promotes proper drainage of middle ear secretions. All these Rasayana, Snigdha, Shita, Madhura, anti allergic and anti biotic properties increase the general and local immunity (Mucosal health).

In Purva Karma for Karna Poorana gentle massage is done with luke warm medicated oil around the ear and pinna. After this heat is applied arround ear with towel soaked in boiling water this causes vasodilation and thus increase permiability of capilaries. Instilled medicine in ear canal gets absorped by skin lining external auditory meatus and tympanic membrane and reaches systemic 
blood flow, according to Ayurveda drugs gets absorped by Bhrajaka Pitta present in skin and shows its effects on body and local tissue (8).

The nasal irritations due to the instilled medicines in form of Nasya as well as the decongestion and antiinflammatory contents of the drug normalize the osteomeatal physiology which again helps in clearance of the secretions of paranasal sinuses thus relives Pratishyaya. In this way it ultimately relives eustechian tube blockage (root cause of $\mathrm{CSOM}$ )

\section{Conclusion:}

- On the basis of similarity between the etiological factors, symptoms, complications, prognosis, and treatment modalities tubotympanic type of CSOM can be correlated with Karna Srava and Perforation of Tympanic membrane seen in active mucosal COM can be compared with Yapya/Krichchha Sadhya, Twaka-Mamsa Gata, Pitta-Kaphaja Dushta Vrana.

- Both the group showed almost equal results in different symptoms. But objectively both group showed insignificant results.

- After completion of treatment audiometric findings showed no changes indicating sensory neural deafness so it can be said that trial drugs are not having ototoxic effect as seen in use of other ear drops for CSOM

\section{References:}

1. Child and Adolescent Health and Development, World Health Organization, Geneva, Switzerland2004.

2. Dhingara P. L., Shruti Dhingara and Deeksha Dhingara. Disease of ear, nose and throat \& Head and neck surgery. 6 ed. India; Elsevier Inc; 1992. 68p.

3. Bhavamishra. Bhava Prakasha with Vidyotini Hindi Commentary by Brahmasankar Mishra. Varanasi; Chaukhambha Sanskrit Bhawan; 2013. 682p.

4. Kaviraj Govind Das Sen. Bhaishajya Ratnavali with siddhiprada commentary. Varanasi; Chaukhamba Surbharati Prakashan; 2005. 838p.

5. Kaviraj Govind Das Sen. Bhaishajya Ratnavali with siddhiprada commentary. Varanasi; Chaukhamba Surbharati Prakashan; 2005. 1020p.

6. George G Browning, Saumil N Merchant Gerard Kelly, lain RC Swan, Richard Canter and William S McKerrow. Scott Brown's Otorhinolaryngology Head and Neck Surgery Vol.3 Part 19. 7ed. London (Great Britain); Hodder Arnold (Publishers) Ltd; 2008. 3408p.

7. Sushruta. Sushruta Samhita with nibandha samgrah commentary of Dalhana. Varanasi; Chaukhambha Orientalia; 2009. 250p.

8. Vagbhata. Ashtanga Samgraha with Commentaries of Sarvangasundara of Arunadatta \& Ayurvedarasayana of Hemadri. 9 ed. Varanasi; Chaukhamba Orientalia; 2005. $513 p$. 